\title{
Static earth pressures on a pile supported excavation in Santiago gravel
}

\author{
Empujes de suelos estáticos sobre una excavación soportada por pilotes en la grava de Santiago
}

\section{Sebastián López}

Universidad Católica del Maule, Ingeniería en Construcción

Campus San Miguel, Avenida San Miguel 3605, Talca (Chile)

slopezr@ucm.cl

\section{Carola Sanhueza}

Pontificia Universidad Católica de Chile, Escuela de Construcción Civil

Ave. Vicuña Mackenna 4860, Macul, Santiado (Chile)

csanhue@uc.cl

\section{Gabriel Candia}

Universidad del Desarrollo, Centro Nacional de Investigación para la Gestión Integrada de Desastres Naturales CONICYT/FONDAP/15110017

Ave. Vicuna Mackenna 4860, Macul, Santiago (Chile)

gcandia@udd.cl

\author{
Manuscript Code: 1096 \\ Date of Acceptance/Reception: 25.03.2019/06.04.2018 \\ DOI: $10.7764 /$ RDLC.18.1.87
}

\section{Abstract}

Concrete soldier piles anchored in multiple levels are the most common method for supporting deep excavations in gravel. Their static design is based on limit equilibrium principles, although these procedures were originally developed for sheet piles or anchored walls on shallow excavations supporting medium-dense sand. The present study draws on the applicability of current design tools to model the static response of deep excavations in stiff gravels and their implications for design. For this purpose, the static response of an anchored pile system was evaluated with a detailed finite element model of a case study, and the results are compared with simplified hand-calculation procedures. The study unit was the $28 \mathrm{~m}$ deep excavation of the Beauchef Poniente building located in the fluvial deposits of the Mapocho River in Santiago. A plain strain model was developed in PLAXIS using the Hardening Soil constitutive model, with parameters determined from large-scale triaxial tests of local gravels, and the computed pile displacement were compared to actual displacement profiles measured with inclinometers. The analysis shows that the simplified procedures provide a reasonably good approximation to the computed earth pressures, internal forces on the piles, and stress in the anchors.

Keywords: anchored piles, excavations, earth pressures, Santiago gravel, stiff soils

\section{Resumen}

Los pilotes de hormigón anclados en múltiples niveles son el método más común para sostener excavaciones profundas en grava. Su diseño estático se basa en principios de equilibrio límite, aunque estos procedimientos se desarrollaron originalmente para tablestacas o muros anclados en excavaciones poco profundas que soportan arena de densidad media. El presente estudio se basa en la aplicabilidad de las herramientas de diseño actuales para modelar la respuesta estática de excavaciones profundas en gravas rígidas y sus implicaciones para el diseño. Para este propósito, la respuesta estática de un sistema de pilote anclado de un estudio de caso se evaluó con un modelo detallado de elementos finitos, y los resultados se comparan con los procedimientos simplificados de cálculo manual. La unidad de estudio fue la excavación de 28 m de profundidad del edificio Beauchef Poniente ubicado en los depósitos fluviales del río Mapocho en Santiago. Se desarrolló un modelo de deformación plana en PLAXIS utilizando el modelo constitutivo de "Hardening Soil", con parámetros determinados a partir de pruebas triaxiales a gran escala de gravas locales, y el desplazamiento del pilote calculado se comparó con los perfiles de desplazamiento reales medidos con inclinómetros. El análisis muestra que los procedimientos simplificados proporcionan una aproximación razonablemente buena a las presiones de tierra calculadas, las fuerzas internas en los pilotes y la tensión en los anclajes.

The depth of underground levels in buildings has increased significantly in recent years due to the greater demand for space in high-density urban areas. In Chile, at the beginning of the nineties, underground levels in Santiago reached depths of 10 to $13 \mathrm{~m}$ (Ortigosa \& Retamal, 1994). Currently, these depths are being exceeded, and such is the case of the Costanera Center Building, with five underground levels to a depth of $20 \mathrm{~m}$, the Titanium La Portada tower, with seven underground levels to a depth of $25 \mathrm{~m}$, and the Territoria 3000 building, with nine underground levels to a depth of $32 \mathrm{~m}$. The latter is the deepest excavation performed to date in Santiago.

To optimize the use of space, these underground levels use the entire building plan area. Their construction requires vertical cuts in the ground and a temporary retaining system. In dense soils without a water table, such as in Santiago 
gravels, the most widely used construction method is RC anchored soldier pile walls (Arias, 1984; Sabatini, Pass, \& Bachus, 1999).

During the different construction stages, it is necessary to know the pile deformations and stress state of the soil to evaluate the global stability of the excavation. Accordingly, the pile performance can be assessed based on ground displacement measurements or indirectly through numerical models. Similarly, the stress state within the ground can be evaluated through a numerical analysis or in an approximate manner using simplified models based on limit equilibrium, and by re-analyzing historical cases. However, there are not enough empirical data to validate the use of these simplified methods in dense gravel, such as in Santiago soils or in excavations of depths greater than $10 \mathrm{~m}$.

Load transfer between soldier piles and the ground is controlled by the "arching effect", which consists of the redistribution of soil stresses due to the local displacement of the ground between stationary points (Bosscher \& Gray, 1986). A detailed study of the interaction between soil and piles is achieved through a 3-D analysis of the problem, which takes into account the rotation of principal stresses between piles (Handy, 1985; Harrop-Williams, 1989; Terzaghi, 1943). Through a 3D finite element analysis, Hashash \& Whittle (2002) modeled the arching effect in deep excavations with clay, and the calculated earth pressure values were consistent with measurements on site; however, the model in the study was limited to walls without anchors. Saez \& Ledezma (2012) modeled the construction sequence and dynamic response of anchored piles in a $12 \mathrm{~m}$ deep excavation in Santiago gravel. Through the numerical analysis, the authors evaluated the redistribution of stresses resulting from the construction sequence and calibrated an equivalent plane strain model to study the dynamic response of the problem, which significantly reduced the calculation time.

Rozic (2012) used inclinometers to measure the deformations in a pile of the Beauchef Poniente Building in Santiago and modeled the construction sequence of the excavation with FLAC $^{2 \mathrm{D}}$ (Itasca, 2005) using an elastoplastic model.

Therefore, the objectives of this research are (i) to develop and calibrate a finite element model for a deep excavation in Santiago gravels and (ii) to compare the magnitude and distribution of earth pressures transferred to the piles obtained from the numerical model and based on simplified methods.

State of the art

The magnitude and distribution of earth pressures in retaining structures vary significantly by construction method and excavation sequence. In particular, during the construction of soldier pile walls anchored at one or more levels, the excavation sequence and installation and stressing of the anchors induce load and deformation patterns in the walls that cannot be correctly approximated by means of traditional limit equilibrium methods (Coulomb, 1776; Rankine, 1857) used to design cantilever walls.

The FHWA-IF-99-015 report 'Ground Anchors and Anchored Systems' (Sabatini et al., 1999), presents a study that describes the excavation sequence and behavior of earth pressures on a low-height wall anchored at two levels with a dry, low-density sandy soil. During the first phase, soil is excavated to just below the first line of anchors, such that the wall behaves as a cantilever and earth pressures approximate the active condition. The upper anchors are then stressed, and the earth pressure significantly increases and, in certain cases, reaches the passive state around the anchors. In the following phase, excavation continues below the upper anchors, creating a pressure bulb around the anchor and redistribution of stresses towards the upper anchors and bottom of the excavation. Similar effects occur with the lower anchor stress and the last phase of the excavation, which results in a pressure distribution that peaks at the anchor level and is lower between the anchors and towards the ends of the wall, as indicated in Figure 1.

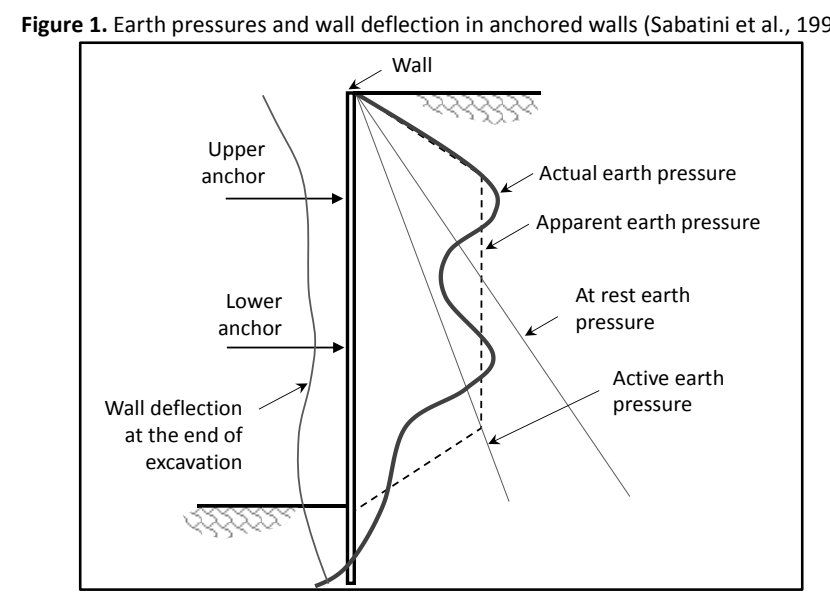


To design anchored piles, it is common to represent non-linear earth pressure distributions through an apparent trapezoidal or uniform earth pressure distribution. The first recommendations to evaluate design pressures were proposed by Terzaghi \& Peck (1967) based on load measurements in the struts of an internally braced excavations. In these recommendations, homogeneous soils and plane strain conditions are assumed. It is also assumed that the walls deform enough to mobilize the full shear strength of the soil. In addition, sands are assumed to behave drained, and clays are assumed to behave in undrained conditions. Several authors have proposed modifications to the method by Terzaghi and Peck (Sabatini et al., 1999).

Design recommendations for anchored, soldier pile walls in Santiago gravel supported with one or two levels of anchors were proposed by Ortigosa \& Retamal (1994). In the first case, the pile is analyzed as a stiff element with an active earth pressure distribution, whereas in the second case, the pile is modeled as a continuous beam with a uniform earth pressure distribution. In the Chilean design code NCh3206 of. 2010 (INN, 2010), the static design of elements with a single anchor level considers the most unfavorable case between uniform and triangular earth pressure distributions and, in the seismic case, considers an inverted triangular distribution. Similarly, for elements with multiple supports, static and seismic designs are performed with a uniform pressure. These methods produce conservative estimations of stress in the anchors, particularly in the seismic case, since recent studies have shown that the inverted triangular pressure distribution is an experimental outcome and not an empirical observation (Sitar, Mikola, \& Candia, 2012).

In summary, previous studies focused on shallow earth retaining systems, such as anchored walls or piles, particularly in soft or low-density soils, which are susceptible to large displacements. The existing literature on anchored piles in deep excavations with dense soils, such as the gravel around Santiago, is scarce, and the applicability of traditional methods requires further analysis.

Methodology

The Beauchef Poniente Building, which is located in Santiago $\left(33.458^{\circ} \mathrm{S}-70.664^{\circ} \mathrm{W}\right)$, is a seven-story reinforced concrete structure with six underground levels and a depth of $27 \mathrm{~m}$. The underground levels have an area of $6200 \mathrm{~m}^{2}$, and their construction was achieved using a temporary excavation system supported by 114 1-m diameter soldier piles spaced at $2.95 \mathrm{~m}$ center-to-center and anchored at three levels. The piles are made of $\mathrm{H} 30$ concrete $\left(f_{c}{ }^{\prime}=25 \mathrm{MPa}\right)$ and have a longitudinal reinforcement area of $81.43 \mathrm{~cm}^{2}$ and transverse reinforcement with an area of $2.01 \mathrm{~cm}$ spaced at $10 \mathrm{~cm}$. The nominal bending strength $\left(M_{n}=1236 \mathrm{kN} \cdot \mathrm{m}\right)$ and shear strength $\left(V_{n}=1360 \mathrm{kN}\right)$ of the pile were estimated based on guidelines in ACI318-14. The excavation plan view and details of the studied pile are shown in Figure 2. On the top of the pile wall, no buildings were found that could generate disturbances or loads on the pile.

The soils present at the site are fluvial sediments known as 'Santiago gravel'. These deposits form two units, called the first and second Mapocho deposits, with average thicknesses of $22 \mathrm{~m}$ and $6 \mathrm{~m}$, respectively. The first deposit is a dense sandy gravel $\left(\gamma=23 \mathrm{kN} / \mathrm{m}^{3}, \varphi=53^{\circ}, c=24 \mathrm{kN} / \mathrm{m}^{2}\right)$ with a natural water content of $4 \%-6 \%$. On top of this gravel is the second and younger deposit, which corresponds to a dense gravel with low plasticity silt $\left(\gamma=22.5 \mathrm{kN} / \mathrm{m}^{3}, \varphi=45-53^{\circ}\right.$, $c=20 \mathrm{kN} / \mathrm{m}^{2}$ ). The water table is below $50 \mathrm{~m}$. For a detailed description of the geotechnical parameters of Santiago gravel, see Kort, Musante, \& Fahrenkrog, (1979) and P. Ortigosa, Musante, \& Kort, (1982). Excavation was performed in eight stages, which encompass the construction of the pile, progress on the excavation, and installation and stressing of the anchors. The details on the construction sequence can be found in Table 1.

The inclinometer data used in this research was obtained from Pardo, Sáez, \& Ledezma (2013), who corrected the data to eliminate the bias-shift error using reduction techniques as those described by Mikkelsen (2003). The pile was instrumented with a digital MEM inclinometer system and readings were taken every $1.0 \mathrm{~m}$ starting at depth of $27 \mathrm{~m}$. The inclinometer, manufactured by RST Instruments, uses bi-axial system to measure inclination on two orthogonal directions, say $A$ and $B$. Once measures are taken along the positive directions, the probe is rotated 180 degrees to measures inclination along the negative directions $A^{-}$and $B^{-}$. These MEMs produce an output signal that is proportional to the sine of the inclination plus a bias or error. The term 'bias shift' of inclinometer readings refers to a systematic error due to a drift of the sensor bias, such that the algebraic sum of the readings on opposite directions or 'checksum' is twice the bias. This bias is initially set to zero at the factory, but its value drifts over time due to aging, wear, and other factors, and must be properly accounted for. 
Table 1. Construction sequence (López, 2014).

\begin{tabular}{ccl}
\hline \multicolumn{2}{c}{ Excavation Depth $(\mathrm{m})$} & Stage description \\
\hline Stage 1 & 0.0 & Pile drilling and construction, $\mathrm{L}=28.5 \mathrm{~m}$ \\
Stage 2 & -4.5 & Excavation of $4.5 \mathrm{~m}$ \\
Stage 3 & -4.5 & $1^{\text {st }}$ line of anchors at $\mathrm{z}=-3.5 \mathrm{~m}$, pre-stress load $1004 \mathrm{kN}$ \\
Stage 4 & -12.5 & Excavation of $8.0 \mathrm{~m}$ \\
Stage 5 & -12.5 & $2^{\text {nd }}$ line of anchors at $\mathrm{z}=-11.5 \mathrm{~m}$, pre-stress load $1297 \mathrm{kN}$ \\
Stage 6 & -20.5 & Excavation of $8.0 \mathrm{~m}$ \\
Stage 7 & -20.5 & $3^{\text {rd }}$ line of anchors at $\mathrm{z}=-19.5 \mathrm{~m}$, pre-stress load $1331 \mathrm{kN}$ \\
Stage 8 & -26.0 & Excavation of $5.5 \mathrm{~m}$, end of excavation \\
\hline
\end{tabular}

\section{Numerical model}

A finite element model of the excavation was developed to evaluate the distribution of the static earth pressures, the internal forces on the piles and stress in the anchors. The simulation was performed in PLAXIS 2D and included the site stratigraphy, a typical pile on the western side of the excavation, and three anchor levels according to the geometric specifications of the project, as shown in Figure 3. The model was discretized using finite elements with 15 nodes and a maximum size of $2.4 \mathrm{~m}$ on the edges and $0.6 \mathrm{~m}$ in the anchor zone. The boundary nodes on the vertical edges were restrained horizontally, whereas the nodes on the model base were restrained vertically. The pile was modeled using $2 \mathrm{D}$ beam elements of rectangular cross section with a moment of inertia equivalent to a set of circular piles spaced at $2.95 \mathrm{~m}$ center-to-center; the three anchors lines were modeled as cable elements with bonded and unbonded segments and pre-stress loads of $T_{01}=1004 \mathrm{kN}, T_{02}=1297 \mathrm{kN}$, and $T_{03}=1331 \mathrm{kN}$ for the top, middle and bottom anchor, respectively. The interaction between the soil and the pile was modeled with PLAXIS's interface element, consisting of two sets of elastic perfectly plastic springs. The construction sequence was implemented according to the stages indicated in Table 1 , which assumed drained conditions for the soil.

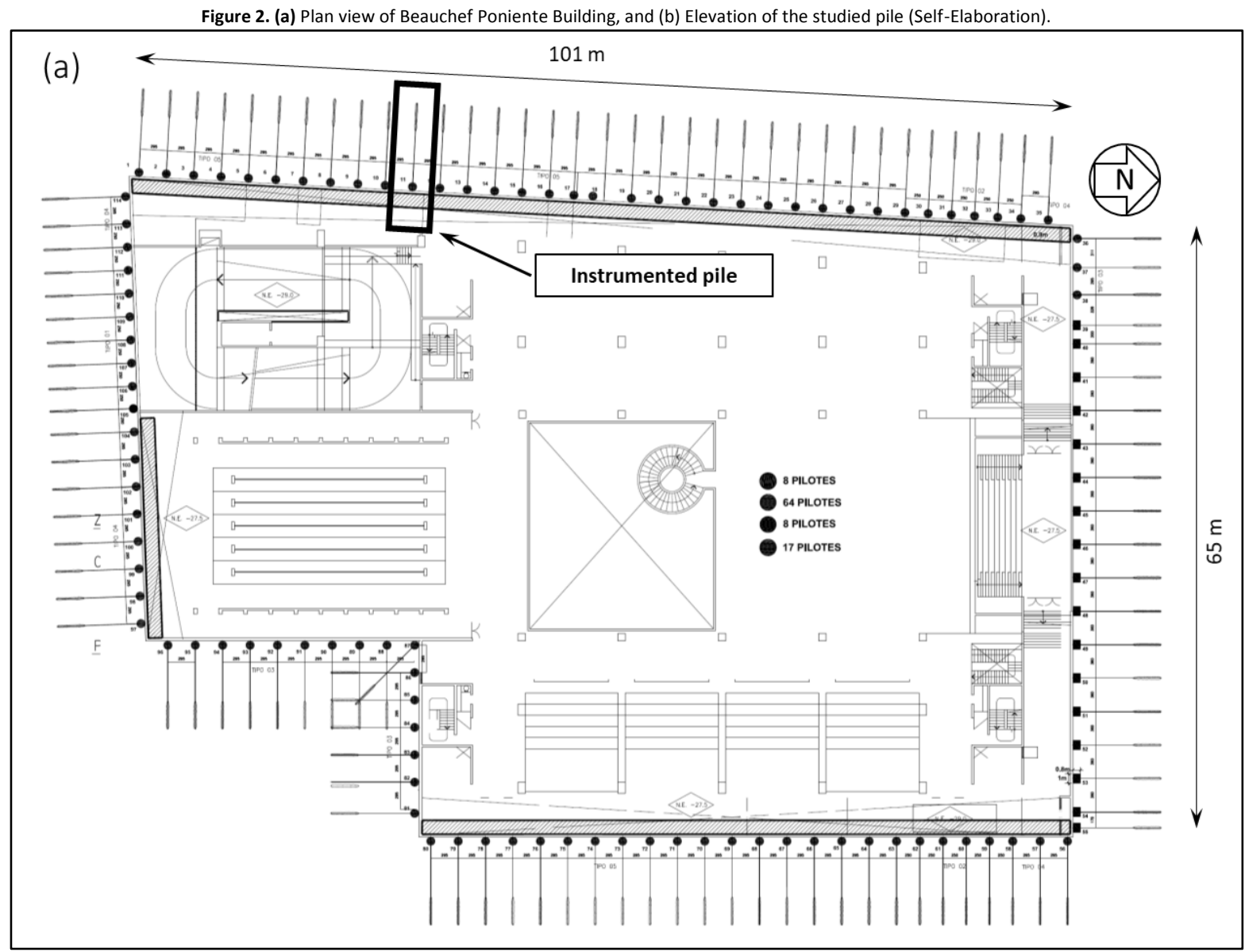




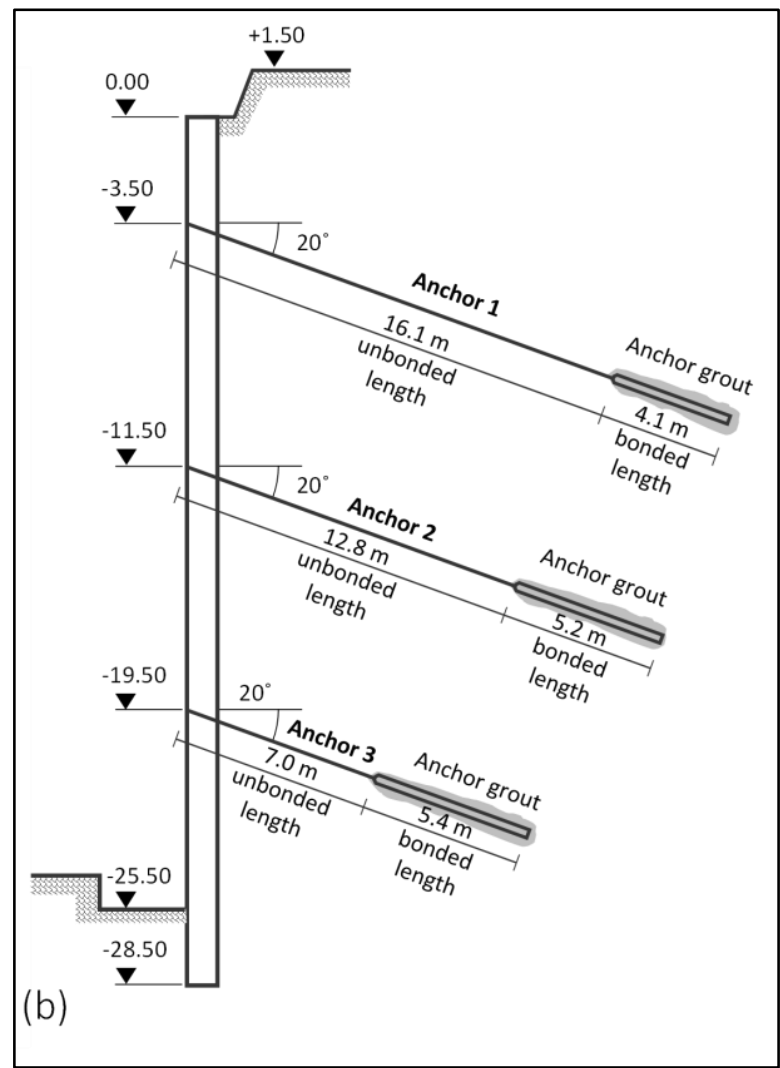

Figure 3. Deformed finite element mesh at the end of Stage 8 (Self-Elaboration).

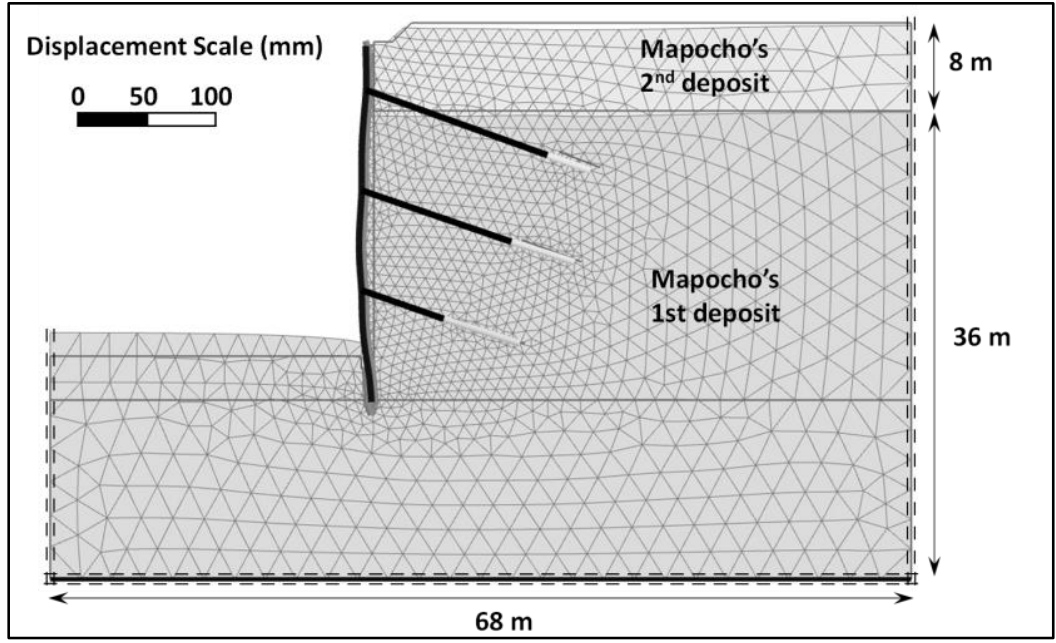

Given that the excavation did not experience large deformations $\left(\Delta / H<1 \times 10^{-3}\right)$, the Hardening Soil constitutive relationship was used (Schanz, Vermeer, \& Bonnier, 1999) to capture the stiffness and non-linearity in the range of small deformations. The shear stiffness and shear strength parameters of the gravels are shown in Table 2; these initial set parameters were determined based on the stress-strain response measured in isotropically consolidated drained triaxial tests for confining stresses of $22 \mathrm{kPa}, 43 \mathrm{kPa}, 60 \mathrm{kPa}$ and $81 \mathrm{kPa}$ (Kort \& Musante, 1978). As seen in Figure 4, the simulated stress strain response of the soil is in good agreement with the measured response. No volumetric response data was available from this set of experiments.

To match the pile displacements measured in situ (Rozic, 2012), the model parameters of the soils described above were further adjusted by increasing the reference Young modulus and Oedometric modulus of the $1^{\text {st }}$ gravel deposit by approximately $17 \%$. In both gravel deposits the at-rest coefficient of earth pressure was decreased by $24 \%$. The critical state friction angle and dilatancy angle were only slightly decreased. The final set of model parameters is also presented in Table 2, and the shear strain response is also shown in Figure 4; the final set of parameters was used throughout the study in all stages of construction. The resulting displacement profiles are shown in Figure 5(a) for different stages. Note that selected model parameters allows a good representation of the wall displacement in stages four through six, however, some differences are apparent in the final stage. 
Table 2. Initial soil Parameters based on the measured triaxial response and final (adjusted) soil parameters based on the measured wall deflection (López, 2014)

\begin{tabular}{lccccc}
\hline & \multicolumn{2}{c}{ Initial parameters } & & \multicolumn{2}{c}{ Final Parameters } \\
\cline { 2 - 3 } \cline { 5 - 6 } Parameter & $1^{\text {st }}$ deposit & $2^{\text {nd }}$ deposit & & $1^{\text {st }}$ deposit & $2^{\text {nd }}$ deposit \\
\hline$E_{50^{\text {ref }}}$ & $136 \mathrm{MPa}$ & $45.5 \mathrm{MPa}$ & & $160 \mathrm{MPa}$ & $45.5 \mathrm{MPa}$ \\
Eoed $_{\text {ref }}$ & $110 \mathrm{MPa}$ & $36.4 \mathrm{MPa}$ & & $128 \mathrm{MPa}$ & $36.4 \mathrm{MPa}$ \\
Eur $_{\text {ref }}$ & $409 \mathrm{MPa}$ & $137 \mathrm{MPa}$ & & $480 \mathrm{MPa}$ & $137 \mathrm{MPa}$ \\
$C_{\text {ref }}$ & $22.6 \mathrm{kPa}$ & $12.3 \mathrm{kPa}$ & & $22.6 \mathrm{kPa}$ & $12.3 \mathrm{kPa}$ \\
$\mathrm{m}$ & 0.5 & 0.5 & & 0.5 & 0.5 \\
$\phi_{\mathrm{p}}$ & $53.3^{\circ}$ & $53.3^{\circ}$ & & $53^{\circ}$ & $53^{\circ}$ \\
$\Psi$ & $23.3^{\circ}$ & $23.3^{\circ}$ & & $23^{\circ}$ & $23^{\circ}$ \\
$V_{\text {ur }}$ & 0.2 & 0.2 & & 0.2 & 0.2 \\
$R_{\mathrm{f}}$ & 0.9 & 0.9 & & 0.9 & 0.9 \\
$\mathrm{~K}_{\mathrm{O}, \mathrm{NC}}$ & 0.33 & 0.33 & & 0.25 & 0.25 \\
\hline
\end{tabular}

Figure 4. Comparison between measured and simulated stress-strain response in triaxial compression tests using the 'initial' and 'final' set of model parameters (SelfElaboration).

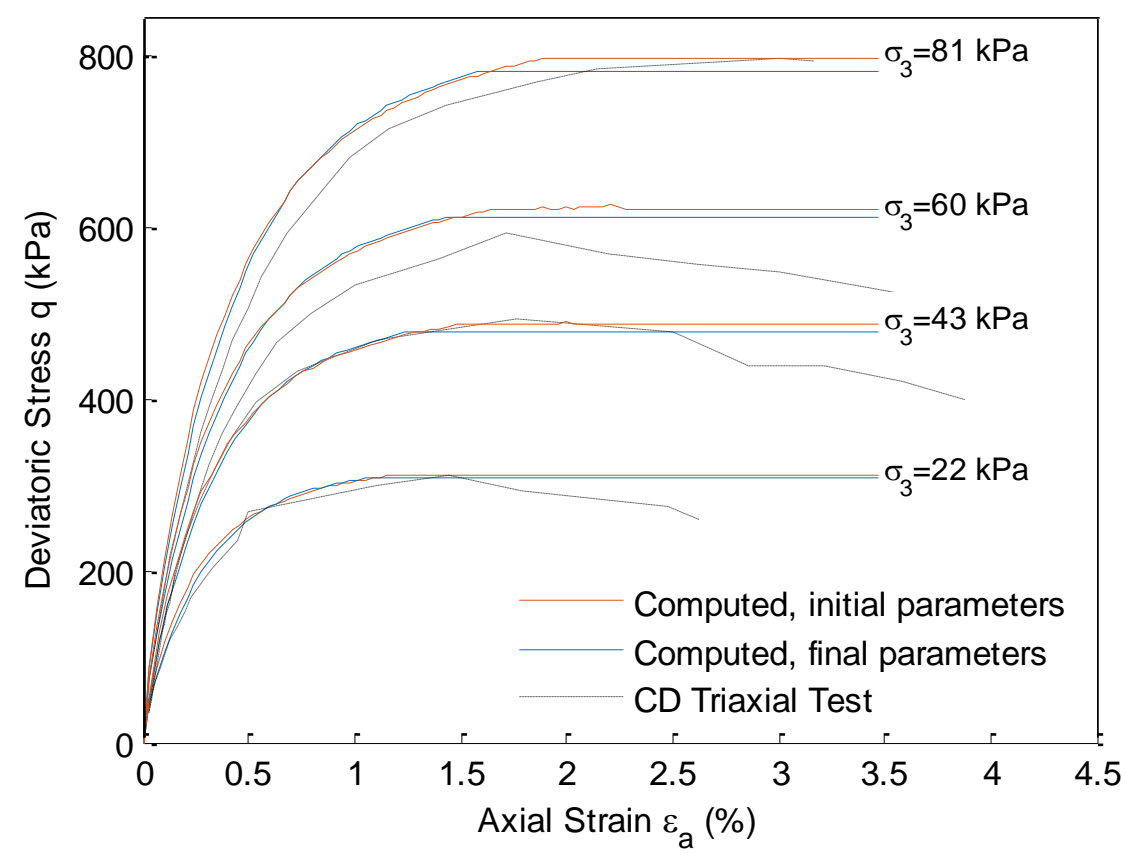

Results and discussion

The lateral earth pressure on the piles computed with the finite element model are shown in Figure $5(b)$ at the end of stages 2,4 , and 8 . These stages represent different boundary conditions in the pile, which correspond to the pile in cantilever, the pile with one anchor level, and the pile with three anchor levels, respectively. For reference, this figure includes the apparent pressure diagram recommended by FHWA (Sabatini et al., 1999) for anchored piles and an earth pressure range limited by the active Coulomb condition $\left(K_{A}=0.11\right)$ and the at-rest conditions $\left(K_{0}=0.20\right)$ computed for a friction angle of $53^{\circ}$. 
Figure 5. (a) Comparison between measured and computed pile displacements, (b) diagrams of computed and apparent earth pressures on the pile (Self-Elaboration).
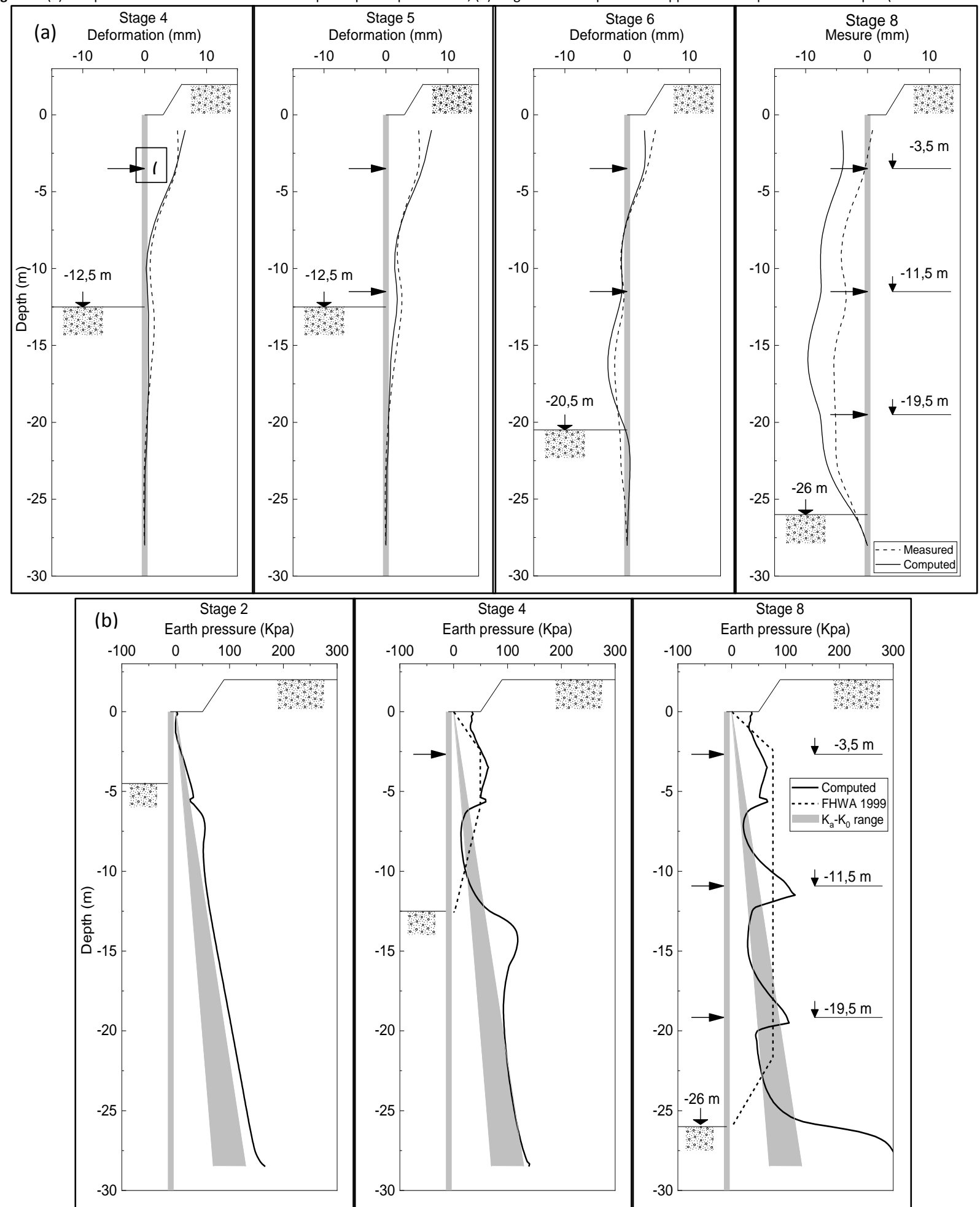

At the end of stage 2, a reduction in the lateral earth pressure on the cantilever pile and a slight increase in pressures just below the dredge line are apparent. At greater depths, there are no significant disturbances on the pile, and therefore, pressures remain near Ko conditions. After stressing the first anchor and excavating down to an elevation of $-12.5 \mathrm{~m}$ (stage 4), the resulting lateral earth pressures adequately fits the trapezoidal distribution proposed by FHWA for a $12.5 \mathrm{~m}$ pile, and the pile deflection beneath the dredge line induces a significant increase in soil pressures. Towards the bottom of the pile, one can see a slight reduction in horizontal pressures as a result of vertical unloading. In the last stage, the pressures obtained from the finite element model are concentrated at the anchor levels, which are greater than the initial at-rest earth pressures. Between anchors, the soil pressure is reduced to a value that approximates the Coulomb active condition, whereas at the bottom of the excavation, the rotation in the pile generates increased pressures due to passive soil resistance. 
Although the apparent pressure distribution proposed by the FHWA does not adequately represent the shape of computed pressures at the final stage, it provides an adequate stress level for designing the pile and anchors for the entire history of the excavation. To evaluate the internal forces in the pile in accordance with the apparent pressure distribution defined by the FHWA, a simplified model of the pile was implemented. It consists of a frame element fixed at the dredge line and lateral supports that represent the anchors, as shown in Figure 6(a). The moment of inertia was defined as $I=0.0491 \mathrm{~m}^{4}$, the young modulus as $E=24 \mathrm{GPa}$ and the trapezoidal pressure diagram with maximum ordinate $p=50 \mathrm{kN} / \mathrm{m}$ as per FHWA specifications. Figure $6(\mathrm{~b})$ shows that the simplified model of the pile correctly reproduces the shear stresses and bending moments obtained from the finite element model. This result validates the use of the trapezoidal-shaped lateral earth pressures in deep excavations with dense gravels, such as Santiago gravels.

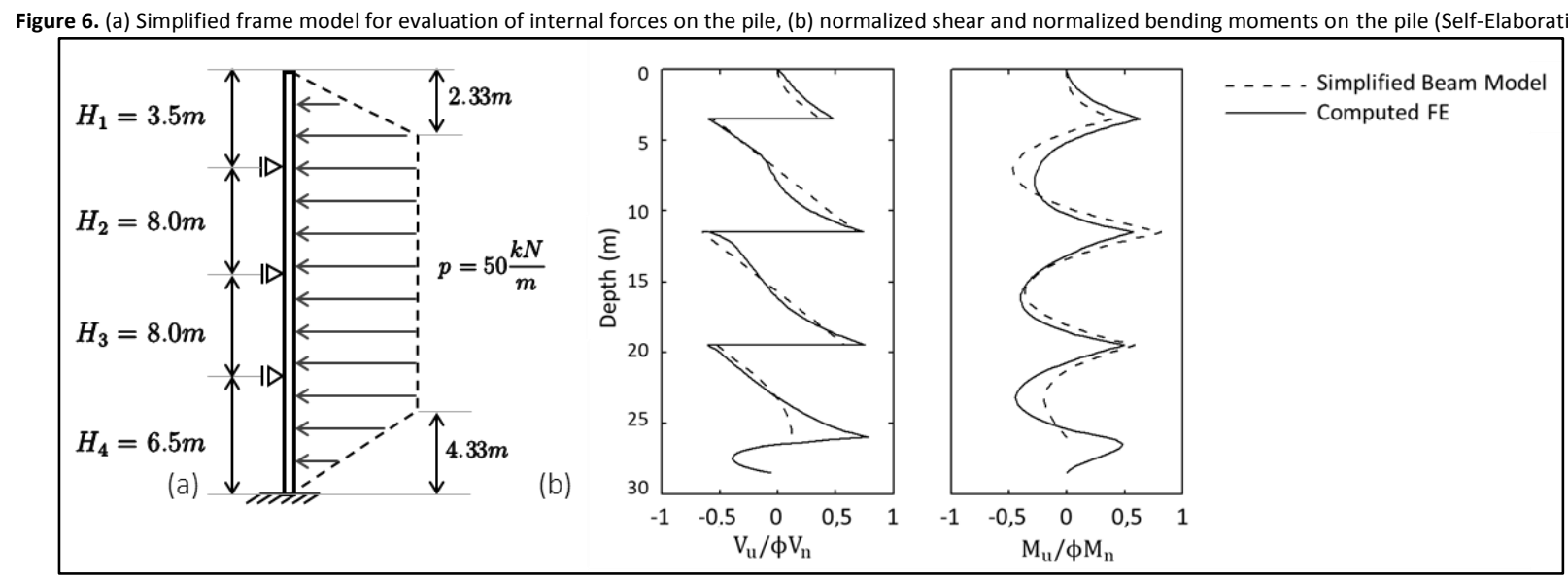

Finally, at the end of the construction sequence the load at the three anchor calculated with the finite element model are $T_{1}=1100 \mathrm{kN}, T_{2}=1350 \mathrm{kN}$, and $T_{3}=1400 \mathrm{kN}$ for the top, middle and bottom anchor, respectively. These values are slightly higher than the loads obtained with the FHWA recommendations based on tributary areas with differences that do not exceed $10 \%$.

A finite element model was developed to simulate the static behavior of a deep excavation in the gravel of Santiago supported by soldier piles anchored at three levels. The numerical model was used to estimate the earth pressures transferred to the pile, internal forces, anchor stress, and to study the applicability of simplified hand calculation methods. From the analysis, the following can be concluded:

- $\quad$ The selection of soil parameters based on shear strength tests available for Santiago gravels is not enough to reproduce the behavior of the pile during the different construction stages. It could be argued that these laboratory tests encompass a limited range of confining pressures. However, this is a recurring problem in geotechnical engineering, in which the predictive capacity of numerical models is at least questionable due to the great heterogeneity of the materials and the broad assumptions of typical numerical models.

- $\quad$ The calibration of the soil parameters with triaxial test data was complemented with displacement measurements obtained with an inclinometer data. To this effect, the Young modulus and Oedometric modulus of the $1^{\text {st }}$ gravel deposit were increased and the coefficient of lateral earth pressure on both deposits were decreased. This final set of model parameters allowed for a good comparison of pile deformations in all the construction stages.

- $\quad$ For the case of the pile supported by a single level of anchors (stage 4), the apparent pressure distribution proposed by the FHWA is a good approximation to the lateral earth pressures calculated with the finite element model.

- With two or more anchor levels, the lateral earth pressures varies significantly throughout the pile and cannot be correctly approximated through a trapezoidal or uniform pressure diagram. However, the trapezoidal distribution is adequate for the design of the pile and leads to slightly conservative values of bending moment and shear forces. 
- The distribution of internal stresses in the pile can be adequately approximated using the simplified model based on frame elements, which significantly reduce calculation times.

Acknowledgements

Financial support for this study was provided by Universidad Católica de Chile and Universidad del Desarrollo. Additional funding and support was provided by the National Research Center on Integral Natural Disaster Management CONICYT/FONDAP/15110017. The authors thank the scientific contributions made by Esteban Sáez.

\section{References}

Arias, J. (1984). Socalzados de Edificios en la Grava de Santiago (Undergraduate Thesis). Universidad de Chile.

Bosscher, P. J., \& Gray, D. H. (1986). Soil Arching in Sandy Slopes. Journal of Geotechnical Engineering, 112(6), 626-645.

Coulomb, C. A. (1776). Essai sur une application des regles des maximis et minimis a quelquels problemesde statique relatifs, a la architecture. Mem. Acad. Roy. Div. Sav., 7, 343-387.

Handy, B. R. L. (1985). The arch in soil arching. Journal of Geotechnical Engineering, 111(3), 302-318.

Harrop-Williams, K. (1989). Arch in Soil Arching. Journal of Geotechnical Engineering, 115(3), 415-419.

Hashash, Y. M. a., \& Whittle, A. J. (2002). Mechanisms of Load Transfer and Arching for Braced Excavations in Clay. Journal of Geotechnical and Geoenvironmental Engineering, 128(3), 187.

Instituto Nacional de Normalización. (2010). NCh 32062010 “Geotecnia - Excavaciones, entibaciones y Socalzados.” Santiago, Chile.

Itasca. (2005). Fast Lagrangian analysis of continua. (Itasca Consulting Group, Ed.) (Itasca Con). Minneapolis.

Kort, I., \& Musante, H. (1978). Ensayos triaxiales in-situ en la grava de Santiago (Estudio de mecánica de suelos). (D. G. de Metro, Ed.). Santiago, Chile.

Kort, I., Musante, H., \& Fahrenkrog, C. (1979). Mediciones en sitio de propiedades mecánicas de la grava para modelo de interacción y cimentación del Metro de Santiago. In Proceedings $6^{\circ}$ Conferencia Panamericaba de Mecanica de suelos de Suelos e Ingeníeria de Fundaciones, Vol. II. Lima.

López, S. (2014). Análisis de la distribución de empujes de suelos sobre subterráneos de gran profundidad en proyecto Beauchef poniente. Pontificia Universidad Católica del Chile.

Mikkelsen, E. (2003). Advances in inclinometer data analysis. In Symposium on Field Measurements in Geomechanics. Oslo.

Ortigosa, P., Musante, H., \& Kort, I. (1982). Propiedades Mecánicas de la Grava de Santiago. In 1 Congreso Chileno de Ingeniería Geotécnica (pp. $442-$ 454). Santiago.

Ortigosa, P., \& Retamal, A. (1994). Socalzados y entibaciones en la grava de Santiago. Revista ONDAC, 1, 19-25.

Pardo, G., Sáez, E., \& Ledezma, C. (2013). Seismic response of a pile-supported excavation on Santiago gravel. In Vienna Congress on Recent Advances in Earthquake Engineering and Structural Dynamics (Vol. 2013). Viena.

Rankine, W. L. (1857). On the stability of Loose Earth. Philosophical Transactions of the Royal Society of London, 147, 9-27.

Rozic, M. (2012). Modelación e instrumentación de las pilas de entibacion del proyecto Beauchef Poniente (Undergraduate Thesis). Universidad de Chile.

Sabatini, P. J., Pass, D. G., \& Bachus, R. C. (1999). Geotechnical Engineering Circular No. 4 Ground Anchors and Anchored Systems (FHWA). Washington D.C., United States.

Saez, E., \& Ledezma, C. (2012). Earthquake-induced pressures on discontinuous piling support on Santiago gravel. Soil Dynamics and Earthquake Engineering, 41, 72-83.

Schanz, T., Vermeer, P. A., \& Bonnier, P. G. (1999). The hardening soil model: Formulation and verification. In Beyond 2000 in computational Geotechnics (pp. 1-16). Balkema, Rotterdam.

Sitar, N., Mikola, R. G., \& Candia, G. (2012). Seismically Induced Lateral Earth Pressures on Retaining Structures and Basement Walls. Geotechnical Engineering State of the Art and Practice, 66(4), 397-408.

Terzaghi, K. (1943). Theoretical soil mechanics. J. Wiley and Sons, inc.: J. Wiley and Sons, inc.

Terzaghi, K., \& Peck, R. B. (1967). Soil mechanics in engineering practice. (Wiley, Ed.) (2nd ed.). Wiley. 